\title{
References
}

1.Eksportna strategija Ukrai'ny (“dorozhnja karta” strategichnogo rozvytku torgivli) na 2017-2021 roky. Shvaleno rozporjadzhennjam KMU vid 27 grudnja 2017 r. № 1017-r. [Export Strategy of Ukraine (Roadmap of Strategic Trade Development) for 2017-2021. Approved by the CMU Decree of December 27, 2017 No. 1017-p.] (2017). Available at: https://www.kmu.gov.ua/ua/npas/pro-shvalennya-eksportnoyi-strategiyi-ukrayini-dorozhnoyi-kartistrategichnogo-rozvitku-torgivli-na-20172021 [Accessed 2.05.2018].

2. Economy Profile of Ukraine. Doing Business 2018 Indicators (in order of appearance in the document) (2018). Available at: http://www.doingbusiness.org [Accessed 1.05.2018].

3. Klaus Schwab (2018), World Economic Forum. The Global Competitiveness Report 2017-2018. Available at: http://www3.weforum.org/docs /GCR2017-2018/05 FullReport/ TheGlobal Competitiveness Report2017 [Accessed 30.04.2018].

4. Klaus Schwab (2014), World Economic Forum, The Global Competitiveness Report 20132014. Available at: http://www3.weforum.org/docs/WEF_Global Competitiveness Report_201314.pdf [Accessed 2.05.2018].

5. The World Bank IBRD-IDA, Doing business (2017). Available at: http://www.doingbusiness.org/data/exploreeconomies/ukraine. [Accessed 30.04.2018].

\section{УДК 368:005.936.3}

Pukała Ryszard

\section{WPLYW UBEZPIECZEŃ NA DZIALALNOŚĆ PRZEDSIĘBIORSTW}

\section{ВПЛИВ СТРАХУВАННЯ НА ОПЕРАЦЇ̈ ПІДПРИЕМСТВ}

Пукала Р.

Pukala Richard

\section{INFLUENCE OF INSURANCE ON ENTERPRISES OPERATIONS}

$W$ artykule przedstawiono zagadnienia dotyczace wplywu ubezpieczeń na działalność przedsiębiorstw, które w ramach swojej działalności narażone sa na szerokie spektrum ryzyk, mogacych zdestabilizować ich funkcjonowanie, a w skrajnym przypadku doprowadzić do ich upadłości. Jedna z metod finansowania ryzyka jest ubezpieczenie, które ze względu na swoja skuteczność oraz niski koszt jest optymalnym z punktu widzenia przedsiębiorstwa sposobem transferu ryzyka. Popyt na ubezpieczenia jest wyrazem przezorności ubezpieczeniowej przedsiębiorców oraz konsekwencja określonego poziomu świadomości ubezpieczeniowej. Pomimo swojej atrakcyjności, sam fakt wykorzystywania przez przedsiębiorstwa ochrony ubezpieczeniowej nie determinuje roli ubezpieczeń w procesie zarzadzania przez nie ryzykiem. Bardzo ważny jest $w$ tym przypadku właściwy dobór ochrony ubezpieczeniowej, aby była $w$ jak najlepszym stopniu dostosowana do indywidualnych potrzeb przedsiębiorstwa.

Stowa kluczowe: ryzyko, przedsiębiorstwa, zarządzanie ryzykiem, finansowanie ryzyka, ubezpieczenia.

У статті представлені питання, щуо стосуються впливу діяльності страхових компаній щзодо їх діяльності піддаються впливу широкого спектра ризиків, які могли б дестабілізувати їх функиіонування, а в крайніх випадках привести до їх банкрутства. Одним з методів фінансування ризику є страхування, яке через його ефективність та низьку вартість $\epsilon$ оптимальним способом передачі ризику з точки зору компанії. Попит на страхування є вираженням страхового прогнозування підприємиів та наслідком певного 
рівня обізнаності про страхування. Незважаючи на свою привабливість, сам факт використання компаніями страхового захисту не визначає роль страхування в процесі управління ризиками. У цььому випадку правильний вибір страхового захисту є дуже важливим, тому він найкращим чином адаптується до індивідуальних потреб компанії. Ключові слова: ризик, підприємства, управління ризиками, фінансування ризиків, страхування.

The article presents the questions related to the influence of insurance companies' activities on their activities exposed to a wide range of risks that could destabilize their functioning, and in extreme cases lead to their bankruptcy. One of the methods of financing a risk is insurance, which, because of its efficiency and low cost, is the best way to transfer risk from the point of view of the company. The demand for insurance is an expression of insurance forecasting of entrepreneurs and a consequence of a certain level of insurance awareness. Despite its attractiveness, the very fact of the use of insurance companies does not determine the role of insurance in the process of risk management. In this case, the right choice of insurance coverage is very important, so it is best adapted to the individual needs of the company.

Keywords: risk, enterprises, risk management, risk financing, insurance.

Współczesna gospodarka rynkowa stwarza działającym w jej ramach przedsiębiorstwom nie tylko określone warunki działania, na bazie których mogą realizować swoje cele strategiczne, ale również wymagania, których spełnienie jest warunkiem funkcjonowania. Otoczenie, w którym funkcjonują współczesne przedsiębiorstwa, podlega ciągłym zmianom i staje się coraz bardziej złożone, narzucając im przy tym konieczność przystosowania się. Wzrasta liczba podmiotów gospodarczych i instytucji, które wpływają na funkcjonowanie poszczególnych przedsiębiorstw, zauważa się też ustawiczne poszerzanie zakresu powiązań przedsiębiorstw $\mathrm{z}$ otoczeniem.

Analizując tendencje gospodarcze w XXI wieku, możemy wyróżnić trzy główne siły, które w znaczny sposób determinują wszelkie aspekty funkcjonowania współczesnych przedsiębiorstw na rynku. Pierwszą z nich jest globalizacja, czyli liberalizacja wymiany wszelkich dóbr i usług wraz z wiedzą i transferem ludzi. Drugą cechą charakteryzującą gospodarkę opartą na wiedzy jest gwałtowny postęp technologiczny, który niesie z sobą bardzo dużo wyzwań i dylematów. Trzecim wyróżnikiem jest wzrost znaczenia kapitału intelektualnego [1, s.143].

Przedsiębiorstwa działające $\mathrm{w}$ ramach gospodarki rynkowej narażone są na szerokie spektrum ryzyk, które mogą zdestabilizować ich funkcjonowanie. Dlatego ważnym aspektem w ich działalności jest podejmowanie działań ukierunkowanych na eliminację lub przynajmniej ograniczenie ryzyka, poprzez wdrożenie mechanizmów zarządzania ryzykiem. Skuteczne i zintegrowane zarządzanie ryzykiem wymaga wkomponowania procesu zarządzania ryzykiem $\mathrm{w}$ proces zarządzania przedsiębiorstwem [2, s.321].

Mówiąc o zarządzaniu ryzykiem w przedsiębiorstwie należy rozważyć sposoby jego finansowania w przypadku materializacji ryzyka. Taką metodą może być ubezpieczenie, które przez wielu przedsiębiorców jest postrzegane jako substytut procesu zarządzania ryzykiem. Ubezpieczenie, ze względu na swoją skuteczność, niski koszt oraz ewentualne dodatkowe korzyści, jest optymalnym z punktu widzenia przedsiębiorstwa sposobem transferu ryzyka. Jednak, sam fakt wykorzystywania przez nie ochrony ubezpieczeniowej nie determinuje roli ubezpieczeń w procesie zarządzaniu ryzykiem. Bardzo ważny jest w tym przypadku właściwy dobór ochrony ubezpieczeniowej, aby była w jak najlepszym stopniu dostosowana do indywidualnych potrzeb przedsiębiorstwa.

Ryzyko jest nieodłącznym elementem działalności każdego przedsiębiorstwa. Nie wdając się w szczegółową jego charakterystykę, najogólniej rzecz biorąc, oznacza niepewność, zagrożenie dla osiągnięcia zamierzonych przez podmiot celów, działanie o nieznanych skutkach. Często definiowane jest także, jako możliwość osiągnięcia sukcesu, niepowodzenia oraz porażki. Przedsiębiorstwo, działając w warunkach ryzyka, powinno wziąć pod uwagę możliwość, że 
inicjowane przedsięwzięcie może się nie udać. W tej płaszczyźnie ryzyko definiowane jest, jako możliwość wystąpienia zdarzenia, które będzie miało negatywne oddziaływanie na realizację założonych celów.

Spektrum ryzyk, na które jest narażone przedsiębiorstwo jest bardzo duże. Kluczowe ryzyka działalności przedsiębiorstw zostały przedstawione na poniższym Wykresie 1.

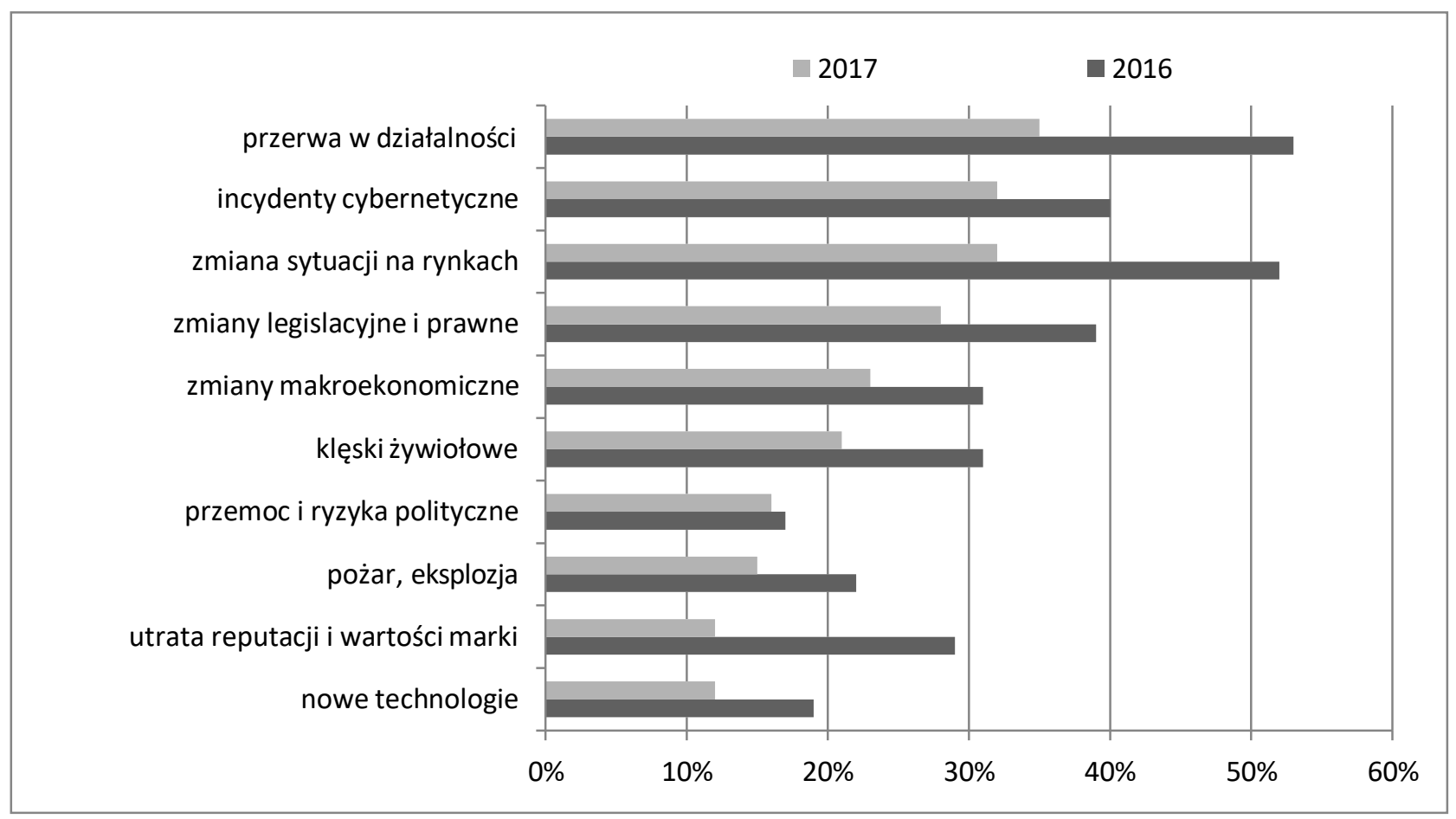

\section{Wykres 1. Dziesięć głównych ryzyk przedsiębiorstw w Europie w latach 2016 i 2017 [9]}

Jak wskazują przedstawione dane, kluczowym ryzykiem zagrażającym przedsiębiorstwu jest przerwa w jego działalności, obejmująca m.in. zakłócenia łańcucha dostaw. Może ona zaburzyć cały proces jego funkcjonowania i doprowadzić do upadłości. Należy podkreślić, iż może się to odbyć w trzech obszarach:

1. Materializacja ryzyka (np. szkoda żywiołowa) następuje wewnątrz przedsiębiorstwa i powoduje zaburzenie jego zdolności produkcyjnych.

2.Zdarzenie występuje u kluczowego poddostawcy, co zaburza proces produkcji $\mathrm{w}$ przedsiębiorstwie.

3. Przerwa w działalności przedsiębiorstwa może skutkować wypowiedzeniem umów ze strony głównych kontrahentów, egzekwowaniem przez nich kar umownych oraz długotrwałą utratą relacji handlowych.

Przedsiębiorstwo powinno więc podejmować działania, których celem jest ograniczenie negatywnych konsekwencji zaistnienia zdarzenia skutkującego zaburzeniem jego działalności, wykorzystując w tym zakresie dostępne narzędzia:

- wdrożenie mechanizmów zarządzania ryzykiem w celu jego monitorowania i niezwłocznego podejmowania działań w przypadku przekroczenia dopuszczalnych wartości lub zaistnienia zdarzenia, ubezpieczeń).

- transferu ryzyka na podmioty zewnętrzne (m.in. dostawców, klientów, zakłady

Majątek polskich firm jest wart 2,8 bln zł. Przedsiębiorcy posiadają maszyny i budynki o wartości 1,8 bln zł. Do tej kwoty należy doliczyć ponad 1 bln zł środków obrotowych w postaci zapasów, należności i inwestycji krótkoterminowych, które 
również mogą być objęte ochroną ubezpieczeniową. Wartość ubezpieczonego majątku polskich organizacji sięga 1,7 bln zł. To prawie 60 proc. całego majątku zgromadzonego przez przedsiębiorstwa. Pożar, uderzenie pioruna, powódź, ale też kradzieże czy zakłócenia produkcyjne to główne ryzyka dla aktywów i działalności firm. Ubezpieczając majątek i działalność produkcyjną, unikają one przestojów w produkcji, zwolnień pracowników, a nawet bankructwa [9].

Zachowanie płynności finansowej to wyzwanie dla każdego przedsiębiorstwa. Głównym zagrożeniem w tym zakresie są zaległości w płatnościach ze strony kontrahentów. Opóźnienia w należnościach to główny problem polskich firm. Dlatego też priorytetem przedsiębiorstw, oprócz zwiększenia zysku (52\%), jest utrzymanie płynności finansowej (37\%) [3].

Polskie firmy miały w 2016 r. przedawnione należności na ponad 2 mld zł. Dla wielu z nich to bardzo duże obciążenie, wpływające na zachwianie płynności finansowej i w konsekwencji zagrożenie upadłością.

Koszty spowodowane opóźnieniami w płatnościach mają duże znaczenie dla działalności przedsiębiorstwa. Są one różne dla różnych branż - vide poniższy Wykres 2.

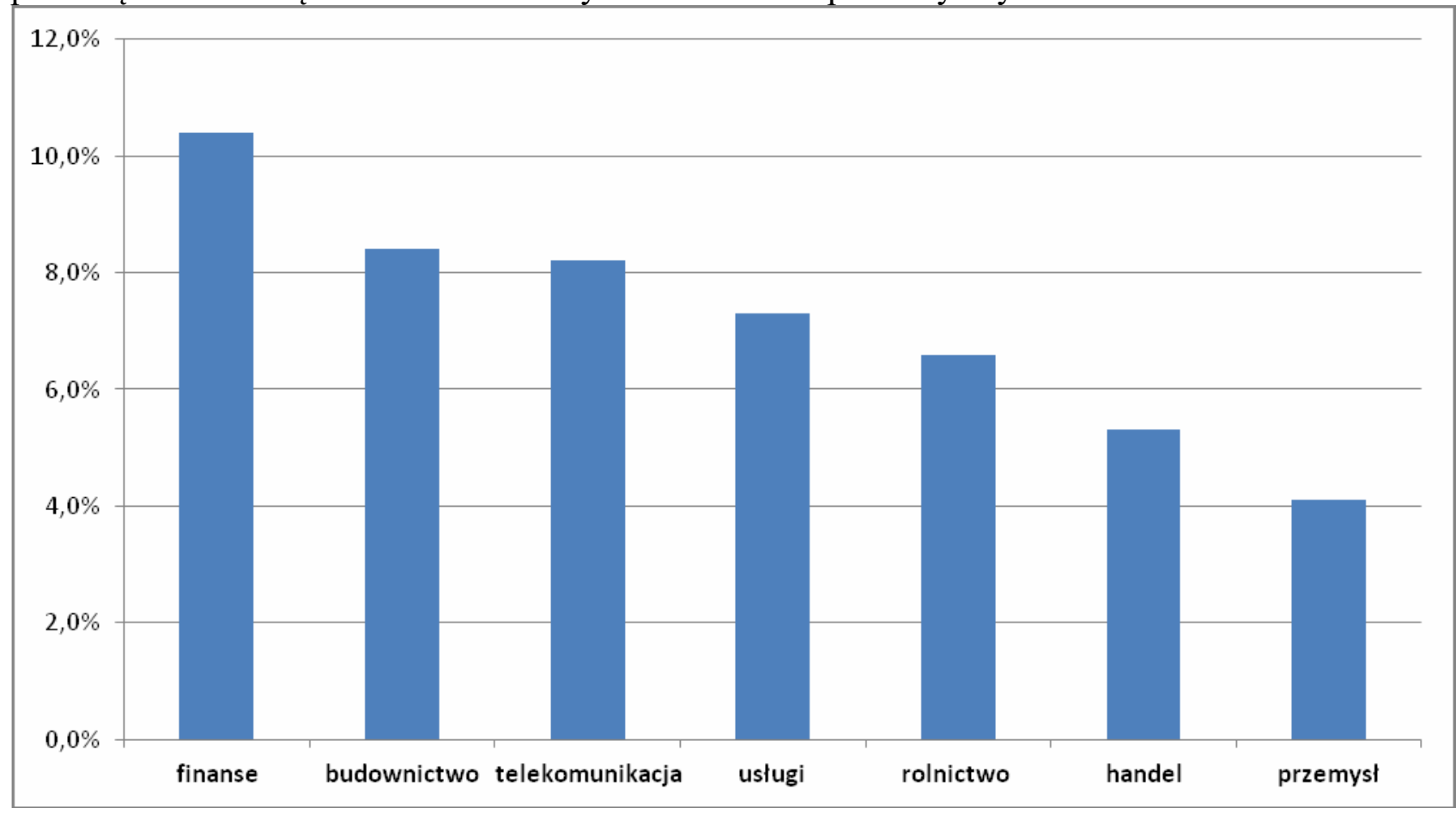

\section{Wykres 2. Koszty powodowane opóźnieniami w płatnościach według branży w 2016 r (\%) [4]}

Ubezpieczenie należności deklaruje już 22\% dużych przedsiębiorców przebadanych przez Deloitte. To pozwala firmom uniknąć zaciągania kolejnych kredytów, które wpędzają firmę w spiralę zadłużenia i grożą bankructwem. W 2016 r. polscy przedsiębiorcy zabezpieczyli obrót swoich firm u ubezpieczycieli na ponad $460 \mathrm{mld}$ zł, niwelując ryzyko w swojej działalności. Gwarancje ubezpieczeniowe pomogły zrealizować tysiącom firm projekty ze środków unijnych. Niemal każdy przetarg, w który zaangażowane są unijne pieniądze, zawiera wymóg zabezpieczenia oferty gwarancją przetargową, natomiast podpisanej umowy - gwarancją zabezpieczenia należytego jej wykonania [9].

W ostatnich latach zauważalny jest dynamiczny wzrost cyberataków na infrastrukturę krytyczną w przedsiębiorstwach lub utrata cennych danych. Stanowią one poważne zagrożenie dla działalności podmiotów i może zakłócić ich działalność.

Przeciętny roczny koszt cyberprzestępstw przypadający na jedną międzynarodową firmę jest szacowany na 12,6 mln zł. Według danych Naukowej i Akademickiej Sieci Komputerowej Państwowego Instytutu Badawczego w 2016 r. było w Polsce 723 tys. prób phishingu, czyli prób wyłudzenia różnymi sposobami od internautów poufnych danych, takich jak loginy, hasła, numery 
kart kredytowych. Największy problem w zakresie zabezpieczeń jest w segmencie małych i średnich przedsiębiorstw, spośród których około 90\% firm nie ma wprowadzonych podstawowych procesów chroniących dane klientów i kontrahentów. Trzeba mieć nadzieję, że ta liczba w najbliższym czasie obniży się, ze względu na wdrożenie $\mathrm{z}$ dniem 25 maja 2018 roku unijnego rozporządzenia o ochronie danych osobowych (RODO), które nakłada na wszystkich uczestników rynku stosowania podejścia risk based approach, czyli podejścia uwzględniającego ryzyko. Przedsiębiorca będzie zobowiązany samodzielnie przeanalizować, jakimi danymi osobowymi dysponuje, co konkretnie się z nimi dzieje i jakie ryzyko się z tym wiąże - a ostatecznie dobrać optymalne środki, które zminimalizują ryzyko nieuprawnionego uzyskania tych danych i ich ochrony. Za regulacjami idą bardzo wysokie kary dla przedsiębiorców nieprzestrzegających wymogów rozporządzenia, sięgające nawet $20 \mathrm{mln}$ euro. Niewątpliwie będzie to wymuszało na przedsiębiorstwach dostosowanie się do nowych uregulowań oraz stosowanie rozwiązań ograniczenia ryzyka, np. w postaci ubezpieczeń [9].

Branża ubezpieczeniowa dokonując akumulacji środków finansowych w postaci rezerw i funduszy ma wpływ na finanse państwa, przedsiębiorstw i obywateli. Wiąże się to z uwolnieniem środków np. przedsiębiorców i wprowadzeniem ich do obrotu w formie inwestycji czy konsumpcji, bądź gromadzeniem w formie oszczędności. Popyt na ubezpieczenia jest wyrazem przezorności ubezpieczeniowej przedsiębiorców oraz konsekwencją określonego poziomu świadomości ubezpieczeniowej. Determinuje go szereg czynników o charakterze makro-, jak i mikroekonomicznym [5, ss.81-101]:

a) czynniki makroekonomiczne to przede wszystkim:

- koniunktura makroekonomiczna;

- poziom edukacji ekonomicznej, ubezpieczeniowej oraz prawnej społeczeństwa;

- skala stosowanego przymusu prawnego w stosunku do podmiotów (zakres ubezpieczeń obowiązkowych);

- zachęty podatkowe;

b) czynniki mikroekonomiczne obejmują:

- cele działania przedsiębiorstwa - deklarowane często przez przedsiębiorców:

- płynność i rozwój w długim okresie, których realizacja jest utrudniona, gdy majątek i procesy będące elementami prowadzonego przedsięwzięcia nie są zabezpieczone poprzez odpowiednie działania właścicieli (prewencja, ubezpieczenie, samoubezpieczenie);

- aktywność przedsiębiorstw w zakresie inwestycji w kapitał rzeczowy; wzrost wartości majątku wymaga doubezpieczenia go w ramach obowiązujących umów ubezpieczenia oraz analizy ryzyk, których pojawienie się związane jest bezpośrednio lub pośrednio z wprowadzaniem nowych rozwiązań technicznych i organizacyjnych;

- kierunek rozwoju przedsiębiorstwa, który w zależności od deklaracji właścicieli ma charakter pracochłonny lub kapitałochłonny i stanowi zasadniczy czynnik w decyzjach dotyczących zabezpieczania ryzyk najbardziej prawdopodobnych dla prowadzonej działalności (dotyczących bądź zasobów ludzkich, bądź majątku);

- sytuacja finansowa przedsiębiorstwa, od jej subiektywnej oceny przedsiębiorcy uzależniają poziom wykorzystywanej ochrony ubezpieczeniowej;

- nawyki ubezpieczeniowe przedsiębiorców, ich motywacje do ubezpieczania majątku i procesów;

- umiejętność oceny ryzyka w przedsięwzięciach prowadzonych przez przedsiębiorców;

- świadomość rozwiązań w zakresie ochrony ubezpieczeniowej dostępnych dla MSP, szczególnych warunków tworzonych na rzecz przedsiębiorców przez ubezpieczycieli;

- poziom zaufania do instytucji rynku ubezpieczeniowego;

- świadomość szczególnej roli pośredników w tworzeniu oferty najkorzystniejszej z punktu widzenia dostosowania do potrzeb indywidualnego przedsiębiorcy;

- kontakt z pośrednikiem, którego rola sprowadza się w dużej mierze do określenia ryzyk charakteryzujących daną działalność i zaproponowania stosownych rozwiązań na rzecz 
ograniczenia ryzyk (bez konieczności orientowania się przez klienta w zakresie oferty rynkowej czy też rozwiązań prawnych); współpraca $\mathrm{z}$ pośrednikiem to nie tylko źródło wiedzy o aktualnych rozwiązaniach dla danego przedsiębiorcy, ale również okazja do edukowania go w zakresie identyfikacji ryzyk i warunków ubezpieczeń w ogóle, czy skali możliwych do prowadzenia działań prewencyjnych;

- zakres działań prewencyjnych, stosowanych przez przedsiębiorstwa w wyniku obowiązku ustawowego, zawartych umów handlowych czy też innych motywów skłaniających podmioty do samodzielnego ograniczania skutków potencjalnych zdarzeń losowych.

Ubezpieczenie jest usługą finansową zapewniającą pokrycie przyszłych potrzeb majątkowych związanych $\mathrm{z}$ likwidacją ujemnych skutków zdarzeń losowych. Ochrona ubezpieczeniowa polega na przejęciu przez ubezpieczyciela odpowiedzialności za mające powstać szkody w zamian za zapłaconą składkę. Ubezpieczenie jest instrumentem gospodarczym, którego celem jest wyeliminowanie lub ograniczenie skutków zdarzeń losowych wpływających negatywnie na zasobność przedsiębiorstwa [6, s.57].

Posiadanie przez przedsiębiorstwa ochrony ubezpieczeniowej wywiera bezpośrednio lub pośrednio pozytywny wpływ na ich kondycję finansową. Analizując, dla przykładu, fakt posiadania ochrony w zakresie ubezpieczenia należności, dla przedsiębiorstwa oznacza:

1. Ułatwienie planowania finansowego:

- zamiana niepewnych warunków otrzymania należności (wpływów kasowych) na pewny wpływ od zakładu ubezpieczeń,

- możliwość podejmowania większego ryzyka biznesowego,

- większa pewność siebie przy podejmowaniu decyzji biznesowych,

2. Wzrost obrotów i obniżenie zapotrzebowania na kapitał obrotowy:

- wprowadzenie konkurencyjnych warunków płatności,

- możliwość zdobywania nowych rynków i pozyskiwania nowych kontrahentów.

- możliwość podejmowania szybkich decyzji.

3. Obniżenie kosztów działalności:

- korzystniejsze warunki kredytu bankowego,

- zmniejszenie kosztów obsługi kredytu,

- redukcja kosztów windykacji należności.

Spektrum potencjalnych zdarzeń skutkujących materializacją ryzyka związanych z funkcjonowaniem przedsiębiorstw jest dużo większe, niż tylko należności. Obejmuje wszystkie obszary ich działalności [7, s.136]:

- personel (związane $\mathrm{z}$ utratą lub czasowym wyeliminowaniem kluczowych dla przedsiębiorstwa pracowników),

- mienie (szkody związane $\mathrm{z}$ budynkami, maszynami, materiałami do produkcji, półfabrykatami, składowaną produkcją),

- przychody (bardzo wrażliwe ze względu na zmiany obrotów),

- odpowiedzialność cywilna (każdy produkt lub usługa ze względu na swoje wady może wywołać konieczność wypłaty odszkodowań),

- zbyt niskie kapitały lub małe doświadczenie i konieczność korzystania z gwarancji.

W tym kontekście należy podkreślić, iż celem nadrzędnym polisy ubezpieczeniowej jest minimalizowanie strat związanych z zaburzeniem procesu działalności przedsiębiorstwa i wsparcie w zakresie optymalizacji kosztów jego funkcjonowania. Dla przedsiębiorstwa posiadanie ochrony ubezpieczeniowej [8, s.78]:

- zwiększa poczucie bezpieczeństwa prowadzonej działalności gospodarczej,

- zwiększa konkurencyjność firmy a także ekspansję rynkową dzięki transferowi części ryzyka na ubezpieczyciela, (np. przez wykorzystanie ubezpieczenia należności handlowych, gwarancje należytego wykonania kontraktu itp.),

- zwiększa wiarygodność i poprawia wizerunek wobec partnerów biznesowych, 
- poszerza dostęp do źródeł finansowania takich jak: kredyt bankowy, leasing, faktoring, środki unijne, pożyczki z funduszy pożyczkowych (przez wykorzystanie ubezpieczeń finansowych w tym ubezpieczeń kredytu, leasingu, gwarancji ), wadium).

- jest często niezbędnym warunkiem przystąpienia do przetargu (gwarancja zapłaty

Spektrum ochrony ubezpieczeniowej oferowanej przez ubezpieczycieli podmiotom gospodarczym jest bardzo duże, a oferowane przez nich produkty są coraz bardziej wyrafinowane i coraz częściej „szyte na miarę”. Sprzyja temu zaostrzająca się konkurencja na rynku, rozwój nowoczesnych mechanizmów zarządzania ryzykiem po stronie klienta i zakładu ubezpieczeń oraz transfer, w wymiarze globalnym, know-how pozwalający na oferowanie programów w największym stopniu spełniających oczekiwania przedsiębiorstwa.

Bezpieczeństwo działalności przedsiębiorstw obejmuje bardzo szerokie spektrum zagadnień związanych $\mathrm{z}$ ich funkcjonowaniem, oraz stosowanych przez nie mechanizmami zarządzania ryzykiem. Należy podkreślić, iż jest to proces ciągły, uzależniony od warunków działania przedsiębiorstw $\mathrm{w}$ zmieniających się uwarunkowaniach rynkowych. Przedsiębiorstwa powinny uwzględniać w swojej aktywności mechanizmy zarządzania i finansowania ryzyka ich funkcjonowania. Duże znaczenie w tym procesie ma zastosowanie ubezpieczeń, które pozwalają na transfer ryzyka do ubezpieczyciela i zapewnienie sobie możliwości rekompensaty potencjalnych strat $\mathrm{w}$ przypadku jego materializacji. Podejmowane $\mathrm{w}$ tym zakresie inicjatywy powinny mieć charakter ciągły i być dostosowane do wewnętrznych warunków funkcjonowania pomiotów oraz uwzględniać zmieniające się czynniki zewnętrzne. Kompleksowość podejmowanych w tym zakresie działań niewątpliwie przyczyni się do zwiększenia bezpieczeństwa funkcjonowania przedsiębiorstw w zmieniających się uwarunkowaniach rynkowych.

\section{Bibliografia}

1. Igielski M., Budowa przewagi konkurencyjnej na bazie zarządzania wiedzą w polskich przedsiębiorstwach, Studia i Prace WNEIZ US nr 44/3 2016.

2. Kaczmarek T., Ryzyko i zarządzanie ryzykiem. Difin, Warszawa 2005, s. 321.

3. Dojrzałość przedsiębiorstw w zakresie zarządzania kapitałem obrotowym, Deloitte 2016, https://www2.deloitte.com/pl/pl/pages/press-releases/articles/brak-plynnosci-finansowej-prowadzido-upadlosci-firm.html.

4. A. Łaszek, P. Białowolski, Zatory płatnicze: duży problem dla małych firm, FOR, 2017.

5. Mikulska A., Świadomość ubezpieczeniowa przedsiębiorców sektora MSP. Wyniki badania praktyk ubezpieczeniowych, Wiadomości Ubezpieczeniowe nr 2/209, Centrum Edukacji Ubezpieczeniowej Sp. z o.o., Warszawa, 2009.

6. Jedynak T., Istota, funkcje, zasady i klasyfikacja ubezpieczeń w: współczesne ubezpieczenia gospodarcze, red. W. Sułkowska, Wydawnictwo Uniwersytetu Ekonomicznego w Krakowie, Kraków 2012.

7. R. Pukała, Ubezpieczenie jako element wsparcia ciągłości działania przedsiębiorstw”, w Pukała R., [red.], „Zarządzanie podmiotami gospodarczymi i instytucjami. Wybrane zagadnienia”, Wydawnictwo PWSTE w Jarosławiu, Jarosław 2012.

8. E. Wierzbicka, Ryzyko małych i średnich przedsiębiorstw i możliwości jego ubezpieczenia, Zeszyty Naukowe PWSZ w Płocku, Nauki Ekonomiczne, t. XXII, 2015.

9. Jak ubezpieczyciele wpływają na przedsiębiorstwa, https://dziekiubezpieczeniom.pl/ ?page_id=233. 